\title{
Francesco Marzano*
}

(iD) https://orcid.org/00oo-0003-2081-6472

\section{Performing death: Marina Abramovićs 7 Deaths of Maria Callas}

\section{Summary}

This essay analyses the opera project 7 Deaths of Maria Callas by Marina Abramović, premiered in Munich in September, 2020. The first section reconstructs the role that the Greek soprano played in the life of the Serbian performer, bringing the latter to a gradual sense of self-identification. Then, the thirty-years-long development of the original concept of the video piece How to Die into the actual project through its various stages is taken into account, and the stage realisation of the work is described in detail. The third section focuses on the representation of death in Marina Abramovićs performances, while section four compares Callas and Abramović's works and lives, and their status as iconic women. The last section retraces Abramovićs artistic path which has led her from her extreme and essential performances of the 1970 s to her recent experimentations with other media and to her meditation on immaterial art.

Keywords: performance, opera, Abramović, Callas, death, icons, presence

* Graduate in Modern Philology, Università Cattolica del Sacro Cuore in Milan; e-mail: francesco_ marzano@hotmail.it 
Every morning the tragedy of being began anew, behind balconies first closed and then opened, as in a Church.

Whether the divine wind blew without purpose or only for the sake of witnesses Then the habits, those sisters of tragedy The sea and its wind won all our most gushing praises Your esse est percipi encountered tremendous obstacles it had to overcome, and every victory was minor, and you had to start over again at once like a plant that continually needs water. P.P. Pasolini, Presence ${ }^{1}$

\section{Callas: a presence in Abramović's life}

Maria Callas died every night anew on the stage, interpreting the tragic destiny of opera heroines in an unusual and psychologically intense way - which was not common for the genre. Pier Paolo Pasolini, in a poem that was addressed to Callas, and is quoted above, tries to fix on paper her ephemeral "presence" and the paradox of her existence - torn between strength and fragility, fame and solitude. A presence that goes far beyond her artistic contribution to opera and which has become mythic. It is difficult to identify which qualities made Callas the "Bible" and the new "model" for opera - as Leonard Bernstein defined her: ${ }^{2}$ the unmistakable timbre of her voice, or the impressive vocal range of about three octaves, which allowed her to explore a huge repertoire, or the "instrumental" sense of singing and the technical skills, or the expressiveness and acting competence... ${ }^{3}$ To be sure, however, other elements contributed to feeding the mythos of the Greek soprano - elements, such as her self-staging (also outside of the theatre), her worldliness, her troubled live and probably, most of all, the convergence of private and

1 P.P. Pasolini, The Selected Poetry of Pier Paolo Pasolini. A bilingual Edition, ed. and trans. by S. Sartarelli with a foreword by J. Ivory, University of Chicago Press, Chicago-London 2014, pp. 399-401.

2 Maria Callas alla Scala. Mostra documentaria a vent'anni dalla scomparsa, Teatro alla Scala, Milano 1997, p. 149.

3 For a rich collection of essays on different aspects of Callas' work and biography, see L. Aversano, J. Pellegrini (eds.), Mille e una Callas. Voci e studi, Quodlibet, Macerata 2016. For her dramatic incisiveness see also G. Guccini, Maria Callas: attrice del Novecento, "Acting Archives Review" 2019, vol. 9, no. 17, pp. 1-47. The most complete bibliography on Callas available online can be found at: https://www.callas-club.de. This and all following URLs last accessed 20.10.2020. 
public life. ${ }^{4}$ So many years after her death in 1977 , the "diva" Maria Callas still conquers new devotees and becomes, again and again, a figure with whom so many can identify, thanks to her complex personality.

Marina Abramović, the "diva" of performance art, has also held a fascination with Maria Callas since she first heard her voice at the age of fourteen, by chance, in her grandmother's kitchen. ${ }^{5}$ "I had become obsessed with Callas, with whom I identified tremendously", writes Abramović in her autobiography Walk through Walls. ${ }^{6}$ She continues, "Callas was my inspiration. [...] I felt such a powerful identification with her. Like me, she was a Sagittarius; like me, she had a terrible mother. We bore a physical similarity to each other. And though I had survived heartbreak, she died from a broken heart." 7 This identification process lasted through the years, and the idea for a piece dedicated to Maria Callas (conceived in 1989) was subsequently developed, and has resulted in the opera project 7 Deaths of Maria Callas - first performed in Munich in September, 2020. ${ }^{8}$

4 See E. Rieger, Ecco un artista: Maria Callas, [in:] M. Abramović, 7 Deaths of Maria Callas. Programmbuch zur Uraufführung, Bayerische Staatsoper, München 2020, pp. 52-59.

5 Ein Gespräch mit Marina Abramović, [in:] M. Abramović, 7 Deaths of Maria Callas. Programmbuch, p. 21.

6 M. Abramović (with J. Kaplan), Walk Through Walls. A Memoir, Penguin Books, London 2017, p. 204.

7 Ibidem, p. 356. For the physical resemblance, compare Callas's portrait by Cecil Beaton (1957) and the picture of Abramović taken by René Habermacher as an homage to Callas (2011), ibidem, p. 357, and see Ein Gespräch mit Marina Abramović, p. 23. For the only, although, substantial difference between Maria and Marina in this mirroring-relationship - i.e. the fact that the first died "of love" and the second survived two separations, those from Ulay and those from Paolo Canevari - see also A. Heyward, Die Verletzliche, "Max Joseph. Das Magazin der Bayerischen Staatsoper" 2019/20, no. 3 ("Loslassen"), p. 31.

87 Deaths of Maria Callas. An opera project by Marina Abramović. A coproduction of the Bayerische Staatsoper, which staged the project for the world premiere on 1 September, 2020 at the Nationaltheater in Munich (with only 500 spectators due to the Coronavirus health and safety measures), and the Deutsche Oper Berlin, Maggio Musicale Fiorentino, the Greek National Opera and Opéra National de Paris, where it will tour in the coming months. Written by Marina Abramović and Petter Skavlan. Director and sets: Marina Abramović. Co-director: Lynsey Peisinger. Film director: Nabil Elderkin. Visual intermezzos: Marco Brambilla. Conductor: Yoel Gamzou. Music: Marko Nikodijević. Sound design: Luka Kozlovacki. Costumes: Riccardo Tisci. Stage design: Anna Schöttl. Lighting: Urs Schönebaum. Dramaturgy: Benedikt Stampfli. Film actress and performance: Marina Abramović. Film actor: Willem Dafoe. Carmen: Nadezhda Karyazina. Tosca: Selene Zanetti. Desdemona: Leah Hawkins. Lucia Ashton: Adela Zaharia. Norma: Lauren Fagan. Cio-Cio-San: Kiandra Howarth. Violetta Valéry: Hera Hyesang Park. Bayerisches Staatsorchester. The project was streamed on 5 September and broadcast on the network television channel, arte, through 7 October, 2020. 


\section{The opera project}

Originally, the idea, born in 1989, was about creating a video piece entitled How to Die. This piece sought to present the juxtaposition of two representations of death - real deaths, on the one hand, filmed among the miners' community in Serra Pelada (once an enormous open pit of a gold mine in Brazil whose infernal conditions have been photographed by Sebastião Salgado in the reportage Gold), and, on the other hand, aestheticized deaths in the form of scenes or recordings taken from operas interpreted by Maria Callas, where the heroines die of love. ${ }^{9}$ The contrast between real and fictive representation of death was intended to shed light on our reactions to death, in particular on our tendency to be emotionally moved by the artistic one in movies, theatre pieces and operas, and, on the contrary, to be annoyed by and to reject real scenes of death, such as those shown on the news in cases of cataclysms: "We don't want to see the reality, but only something, that is played for us." 10 And again: "When we see death staged beautifully in opera or film, we cry and have emotions. But when we see real death, on television or internet, it's horror, we can't deal with it."11 Opera, with its tendency towards great tragedy, seemed, to Abramović, to be the best form of art for reflecting on death. Statistics say that at about every three minutes, one person on the earth dies. This revelation led the performance artist to think of creating 3-minute video sequences for each death and, then, combining the sequences with an opera aria. ${ }^{12}$ As a result of this conception, Marina Abramović travelled to Serra Pelada, with the support of the French Minister of Culture, and made contact with the miners there. The project eventually had to be interrupted, however, due to financial constraints. Abramović had wanted to commission seven different fashion designers to create costumes for the opera segments that she, herself, would have directed, as well, but this aspect of the project turned out to be too expensive.

A further step towards the realisation of the project was made some years later, in 2013, in Oslo, Norway, where Marina Abramović met the screenwriter Petter Skavlan. ${ }^{13}$ At this time, the two agreed on the need to make the project simpler, while also agreeing to substitute the documentary footage of actual deaths with

9 See M. Abramović, Walk Through Walls, pp. 203-205 and J. Westcott, When Marina Abramović dies. A Biography, Massachusetts Institute of Technology, Cambridge 2010, pp. 223-224.

10 Ein Gespräch mit Marina Abramović, p. 22. My translation.

11 From the interview in A. Heyward, Die Verletzliche, p. 28. I wish to thank the Bayerische Staatsoper, in particular, Ms. Sophia Lechner, for kindly making the original English version of this interview available to me. For the "spectacle of death" and the "uncanny ambiguity" that pervades tragic theatre, see also H.-T. Lehmann, Tragedy and Dramatic Theatre, trans. by E. Butler, Routledge, New York 2016, p. 29.

12 See A. Heyward, Die Verletzliche, p. 28.

13 See M. Abramović, Walk Through Walls, pp. 356-357. 
scripts fashioned from seven operas. Abramović, herself, was to act out the scripts while Callas' voice resonated. This iteration of the project would see a parallelism coming into being in which the man scripted as standing next to the heroine in the opera (who either stays with her or eventually kills her) would represent the shipping magnate Aristotle Onassis - a figure with whom Maria Callas had had an intense love affair, but who had left her in order to marry Jacqueline Kennedy. The male role, in the video installations, was to have been played by the actor Willem Dafoe. Dafoe and Abramović had already collaborated once on the theatre piece The Life and Death of Marina Abramović, by Robert Wilson (2011).14 Additionally, between the scripted scenes, the plots of the operas would be summarized and condensed to their essence in less than ten sentences. The fashion designer of Burberry, Riccardo Tisci, was slated to make the costumes, and seven different film directors were to direct the videos.

This second stage of the project's development was very close to the one that was finally realised at the Nationaltheater in Munich. In 2017, when Abramović was in Stockholm, Sweden, for her first major retrospective in Europe - The Cleaner at the Moderna Museet ${ }^{15}$-, the general director of the Bayerische Staatsoper, Nikolaus Bachler, proposed a collaboration in which he would abandon the idea of letting her stage the opera Bluebeard's Castle by Béla Bartók, in favour of producing the Callas project. ${ }^{16}$ As a result, the last three years - from 2017 to 2020 - had been dedicated to preparing for the premiere which was to have taken place on 11 April, 2020. Unfortunately, owing to the Coronavirus pandemic, the long-awaited event had to be postponed. Recent rehearsals have been held using every precautionary measure available to prevent the spreading of the virus. Working in an almost empty opera house; focusing, unusually, on one single production at time - this precarious situation, and the monastery-like atmosphere it has produced has turned out to be ideal for the artists to be able to concentrate on the theme of death. ${ }^{17}$ At the age of 73 , Abramović has succeeded in realising a project that had been pending in her agenda for 31 years and which will probably lead to further artistic "side-products". 18

\footnotetext{
14 Ibidem, pp. 334-338.

15 See L. Essling (ed.), Marina Abramović - The Cleaner, Hantje Cantz, Berlin 2018.

16 See Offen gesprochen. An open conversation. Marina Abramović and Nikolaus Bachler, available at https://mediathek.staatsoper.de/playlist/7-deahts-of-maria-callas.html

17 Ibidem.

18 See the preparatory sketches and drawings made in pencil, spit, blood and tears on paper, which can be seen as storyboards for 7 Deaths, [in:] M. Abramović, Drawings 1963-2017, Henie Onstad, Høvikodden 2018, pp. 12-13 and 355-365. In connection with the opera project, Marina Abramović also realised some film projects which have not yet been published, with the exception of Spirit House - Insomnia (1997): see K. Dillkofer, Marina ist nicht Maria ist nicht Violetta, [in:] M. Abramović, 7 Deaths of Maria Callas. Programmbuch, pp. 14-15.
} 
From the performances of the ' 70 , reduced to the essential, passing through the experience of video-making and theatre, up to this grandiose opera project, the way was long but it was not surprising: Marina Abramović has become more and more open to other media, and opera offers a fertile ground for experimenting with "crossovers". Since its birth, moreover, opera has always taken advantage of other art forms, such as dance, pantomime, painting and architecture, and has had a central role in the debate on the Gesamtkunstwerk. ${ }^{19} 7$ Deaths of Maria Callas in its final version, consists of seven videos, all directed by Nabil Elderkin, where Marina Abramović and Willem Dafoe act out different kinds of death, each inspired by seven operas. ${ }^{20}$ Most of the filmed sequences are in slow motion, a device that painfully dilates the deaths and at the same time increases the power of their aesthetic experience. The initial idea of showing real death scenes was abandoned. As the videos are projected onto a screen that spans the entire stage, seven sopranos take turns singing a famous aria taken from the respective opera (not necessarily from the death scene), all costumed in the same white dress. Between the arias, we see video interludes with clouds and storm images (by Marco Brambilla) over which Abramovićs voice can be heard reading lines that describe, in a poetic and evocative way, the essence of the respective deaths. ${ }^{21}$ Just as evocative are the links between the videos, the opera arias, Maria Callas' life and Marina Abramovićs past performances. The music, by Marko Nikodijević, holds the arias together and serves to frame to the entire work, with newly composed orchestral overture at the beginning and a long final scene for the eighth death, performed on stage by Marina Abramović. During the first, hour-long part of the project, Marina Abramović lies on a bed under a spotlight on the right side of the stage, while the singers perform at the foot of her bed, as in a mourning ritual. The death scenes succeed each other as follows:

1. Violetta dies of tuberculosis. During the aria Addio, del passato bei sogni ridenti, from the third act of Giuseppe Verdi's La Traviata, the video shows the ill woman exhaling her last breath, while a gust of wind blows out one of two burning candles on the nightstand close to her. The man stands by her.

2. Tosca plunges into the depths. During the aria Vissi d'arte, vissi d'amore, from the second act of Giacomo Puccini's Tosca, the video takes place in New York

19 E. Huttenlauch, Marina Abramović und die Parrhesie, [in:] M. Abramović, 7 Deaths of Maria Callas. Programmbuch, p. 75.

20 For the choice of the number seven with its symbolic and biographical implications, see Ein Gespräch mit Marina Abramović, p. 24.

21 The texts written by Petter Skavlan can be read (albeit with slight differences to the final performance) in M. Abramović, 7 Deaths of Maria Callas. Programmbuch, pp. 10-11 and in M. Abramović, 7 Deaths of Maria Callas, photographs by M. Anelli, Damiani, Bologna 2020, pp. $15,33,53,73,95,119,141$. 
and, first, shows the woman cradling the body of the man as in a pietà, and, then, it shows a free fall of the woman from top of a skyscraper. ${ }^{22}$ The link to the opera's finale, where Tosca bemoans the death of her beloved Cavardossi and, then, jumps off of the bastions of Castel Sant'Angelo, is clear.

3. Desdemona is strangled by Otello. During the aria Ave Maria, from the fourth act of Giuseppe Verdi's Otello, the video shows the man placing three pythons around the neck of the woman who is sitting on a throne-like chair. The pythons slowly wrap around the neck of the woman, while the man observes her suffocation. ${ }^{23}$ In the opera Otello, himself, strangles Desdemona.

4. Cio-Cio-San commits suicide. ${ }^{24}$ During the aria Un bel di vedremo, from the second act of Giacomo Puccini's Madama Butterfly, the video transposes the last scene of the opera onto an apocalyptic setting, where green poison gases force men to wear protective suits. When the man (the U.S. naval officer, Pinkerton, in the opera) arrives to take the little son (who is playing, unawares, with a small American Flag) away from the mother (Cio-Cio-San), she takes off her suit and stifles - falling to the ground and dying in an hostile environment: one that mirrors that of Cio-Cio-San, who was disowned by her family and abandoned by the husband. The voice-over in the cloud sequence mentions the "butterfly effect" (small causes leading to unpredictable consequences), adding an ecological and dystopian meaning to the scene. ${ }^{25}$

5. Carmen is stabbed by Don José. During the aria L'amour est un oiseau rebelle, from the first act of Georges Bizet's Carmen, the video takes place in a bullfight arena, directly recalling the final scene of the opera in Seville. The woman wears a traditional toreador dress and the man is dressed in black. The latter throws

22 Abramović had already used the pietà symbolism in two works with Ulay in 1983: in the theatre piece Positive zero (see M. Abramović, Walk Through Walls, p. 154) and in the video Anima mundi from the series Modus vivendi (see M. Abramović, Artist Body. Performances 1969-1998, Charta, Milano 1998, p. 257).

23 The video is actually a reperformance of Abramović's Dragon Heads, first performed in 1990: see M. Abramović, Walk Through Walls, p. 227 and M. Abramović, Artist Body. Performances 1969-1998, pp. 314-321.

24 Referred to as hara-kiri, the Japanese ritual suicide by disembowelment in the name of honour (see M. Abramović, 7 Deaths of Maria Callas, p. 71), even though Cio-Cio-San slits her throat.

25 M. Abramović, 7 Deaths of Maria Callas. Programmbuch, p. 10. Note that this same effect is mentioned by E. Fischer-Lichte, The Transformative Power of Performance. A new aesthetics, trans. by S.I. Jain, Routledge, New York 2008, p. 206, to describe the complexity of the globalized societies, where even modern science contributes to the notion that within the human being, itself, mysterious and unpredictable forces are at work which contribute to the "re-enchantment" of the world, and with which the aesthetics of the performative puts us in contact. 
a lasso around the woman's body and they initially play a kind of tug-of-war, suggesting, both, courtship rituals (underscored by the playful glances between them and by the sensual habanera aria) and, at the same time, an actual fight between toreador and bull. Although, at the beginning, the costumes could suggest that the woman symbolizes the toreador and the man the bull, the roles become unclear afterwards, and overlap in the finale of the opera: she pulls out a dagger and tries to cut the ropes around her body, but the man grabs the dagger and stabs her, just as Don José kills Carmen. ${ }^{26}$ Who is the human being and who is the animal? Who wins and who is conquered? And what kind of fight do we see? Everything blurs into the symbolic impact of the scene. ${ }^{27}$

6. Lucia dies of madness. During the aria Il dolce suono, from the third act of Gaetano Donizetti's Lucia di Lammermoor, the black and white video shows an elegant room full of mirrors where the woman sits in a white wedding dress, initially covered by a veil. She launches into, what seems to be a fit of anger, a bout of despair and an attack of madness all-at-once (perfectly corresponding with the "madness" aria sung by the soprano). She destroys the mirrors around her, tears her garments and smashes three vases, one of which against her chest, making it bleed. The last sequence shows the woman as a martyr (Saint Lucy?), or a Madonna bleeding from her eyes (Photo 1) and, then, spreading the blood all over her face and chest. ${ }^{\mathbf{2 8}}$

26 The explanatory text in the "cloud" sequence reinforces the ambiguity of the roles by emphasizing Carmen's strength, even though, in the end, she dies: "Her fearlessness fascinates me. Her love of freedom mirrors mine. Her smoldering sexuality empowers her. [...] Love guides her hearth" (M. Abramović, 7 Deaths of Maria Callas. Programmbuch, p. 11).

27 For the aesthetic relevance of the corrida in its traditional context, where life and death, as well as oppressor and victim tend to overlap, see the last chapter of Thomas Mann's Confessions of Felix Krull, confidence man, trans. by D. Lindley, Vintage International, New York 1992. For example: "I call him a sacrifice because one would have to be dull indeed not to fell the atmosphere that lay over all, at once oppressive and solemnly joyous, a unique mingling of jest, blood, and dedication, primitive holiday-making combined with the profound ceremonial of death" (p. 375); "this teaching contained something that united its believers irrevocably, joining them in life and in death; and its mystery consisted in the equality and identity of slayer and slain, axe and victim, arrow and target..." (p. 379). For the concept of Homo aestheticus in Thomas Mann and the identity of life and art through imitation - which is a central issue in 7 Deaths of Maria Callas, as well - see F. Rossi, Variazioni poetiche di modelli evolutivi. Thomas Mann e l'Homo aestheticus, "Prospero" 2014, vol. 19, pp. 121-142.

28 For Marina Abramović's interest in the repertoire of images and symbols of mysticism, see the photo and video-series The Kitchen: Homage to Saint Teresa (2009): M. Abramović, Walk Through Walls, pp. 305-306. In general, on spirituality in Abramović's works, between Shamanism, Buddhism and rituals of the Aboriginal, in addition to her autobiography, see the documentary Marina Abramović in Brazil: The Space in Between, directed by M.A. del Fiol, 
7. Norma goes into fire. On the aria Casta Diva, from the first act of Vincenzo Bellini's Norma, the video shows man and woman, hand in hand, running into the flames, just as Norma, the high-priestess of the druids, and her lover, the Roman proconsul Pollione, do in the finale of the opera. There are some references to scenes from the other videos in the work. For example, the woman wears male attire, with the same shoes as the man in Carmen's scene (n. 5), while the man wears the gold sequin dress we'll see in the eighth scene.

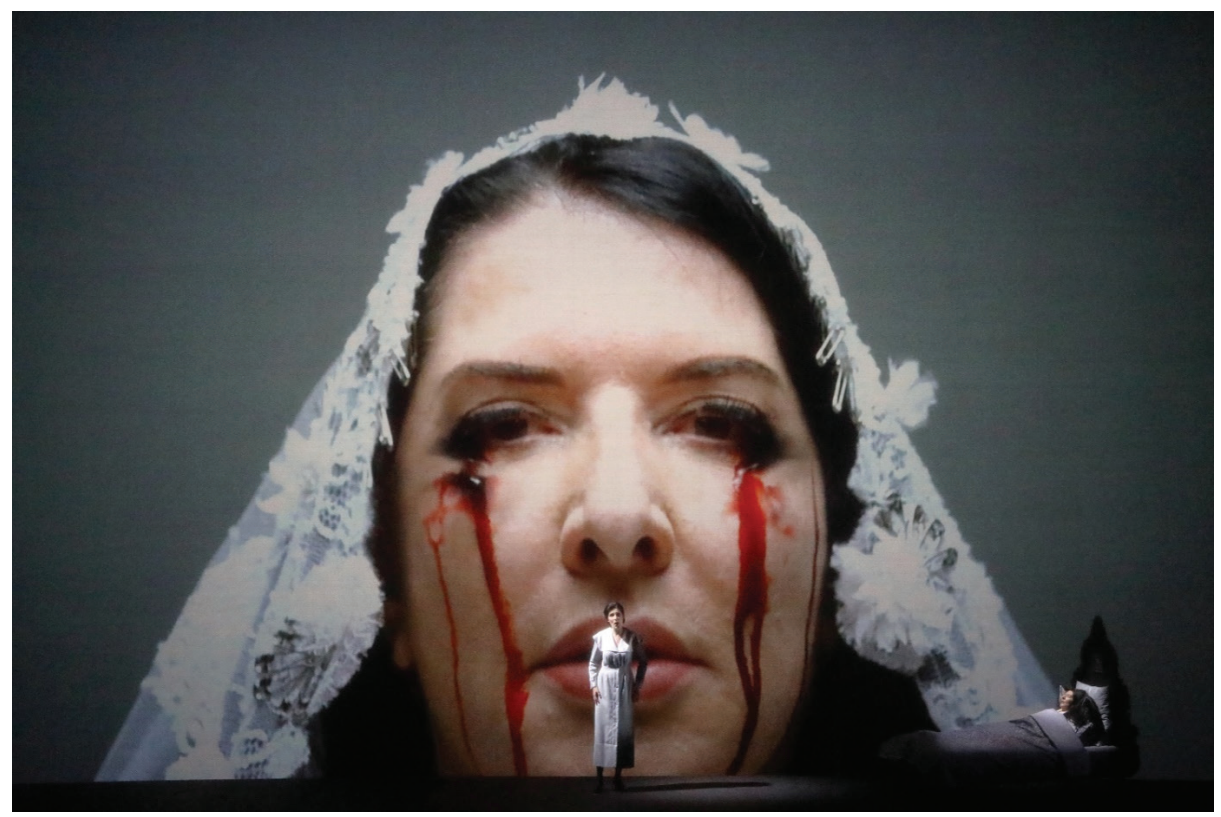

Photo 1. Lucia dies of madness from 7 Deaths of Maria Callas. Adela Zaharia (in the middle), Marina Abramović (on the right). (c) Bayerische Staatsoper, Wilfried Hösl

Maria Callas dies of a broken heart. For the eighth scene there is no video. In its place is a performance by Marina Abramović, herself. Around the bed where Abramović lay the whole time, the stage setting accurately reproduces the bedroom of Maria Callas as it was in her last residence (36 Avenue Georges-Mandel in Paris), where she spent her last years living largely in isolation and eventually died of a heart attack at age 53 on September 16, 1977. Marina Abramović supports the thesis that the primary cause of Maria Callas' death was heartbreak. She neglected her work and her voice after falling in love with Aristotle Onassis. Even though his marriage with Jacqueline Kennedy was a massive shock for Callas, she didn't stop loving him, and after he passed away in 1975, "she became a recluse in her Paris

2016, and D. Zuber, Leuchtkraft im Norden - Die Verortung des Spirituellen in der Kunst der Marina Abramović, [in:] L. Essling (ed.), Marina Abramović - The Cleaner, pp. 252-262. 
apartment, where she died of heart failure. [...] She didn't want to live anymore. She actually died for love."29 For the performance, Marina Abramović abandons her motionless lying position and, following the instructions of the voice-over (her own voice), she slowly begins to become animated ("Breath... Swallow... Open your eyes..."). ${ }^{30}$ The voice-over text is fragmented and follows the stream of consciousness of the woman, mixing up sensations of the awakening with memories evoked by the place (friends of Callas are evoked and are almost begged: "Where are you all now?"). Abramović does not speak and follows, as a puppet, the movements prescribed by the voice ("Push the duvet aside. Lean forward. Turn..."), which guides her through the room - counting, altogether, 17 steps. Some actions are, however, autonomously performed. While the chorus, mid-sequence sings "The rite is over", she moves a vase on the small table in the foreground, takes some photographs out of a drawer, chooses one showing her and her ex-husband, Paolo Canevari, leans it against the vase, smashes the vase on the floor (as a veiled reference to the sixth video of Lucia di Lammermoor). ${ }^{31}$ The voice-over keeps counting the steps during an epic crescendo of the orchestra until Abramović opens the window and an intense ray of daylight pervades the room. The music fades out and ends while Abramović leaves the scene in a trance-like state - following the beam of light. In the following sequence the seven sopranos who had sung the respective arias act as members of a cleaning company, or maid service, cleaning up and disinfecting the room and covering every piece of furniture with black veils. At the same time, on a sound carpet made of distorted fragments from the arias, the voice-over (this time recorded by Dafoe) quotes lines spoken by the male lovers of the dead heroines (Cavardossi, Otello, Pinkerton, Don José, Edgardo, Pollione), all making love declarations to their women. The last maid turns on the record player - which gets stuck, repeating the same fragment over and over - and turns off the light. At this point, a recording with Maria Callas' interpretation of the aria Casta Diva, from 1954, can be heard playing and Marina Abramovć walks on stage with the already mentioned gold sequin dress from the seventh scene. She reproduces,

29 M. Anderson, The Coronavirus Derails Marina Abramovic's Maria Callas Opera, "New York Times" 9.04.2020, https://www.nytimes.com/2020/04/09/arts/music/marina-abramovicmaria-callas.html. See also Ein Gespräch mit Marina Abramović, p. 23 and A. Heyward, Die Verletzliche, p. 28.

30 The script of the eight death, written by Marina Abramović and Petter Skavlan, is published in M. Abramović, 7 Deaths of Maria Callas, pp. 161-171, but differs in the ending with the actual version of the premiere, where two main elements have been omitted (Marina Abramović taking all the costumes from the films out of the wardrobe and throwing them on the bed, and her leaving the stage towards the audience) and substituted, as described, in the following text.

31 Compare the pictures with Paolo Canevari in M. Abramović, 7 Deaths of Maria Callas. Programmbuch, p. 145 and M. Abramović, Walk Through Walls, p. 286. 
in a kind of tableau vivant, typical gestures and mimics of Maria Callas (Photo 2). In the end what remains is Maria Callas' body as a symbol - here, present, or even re-incarnated in Marina Abramovićs body - and, most of all, in her voice.

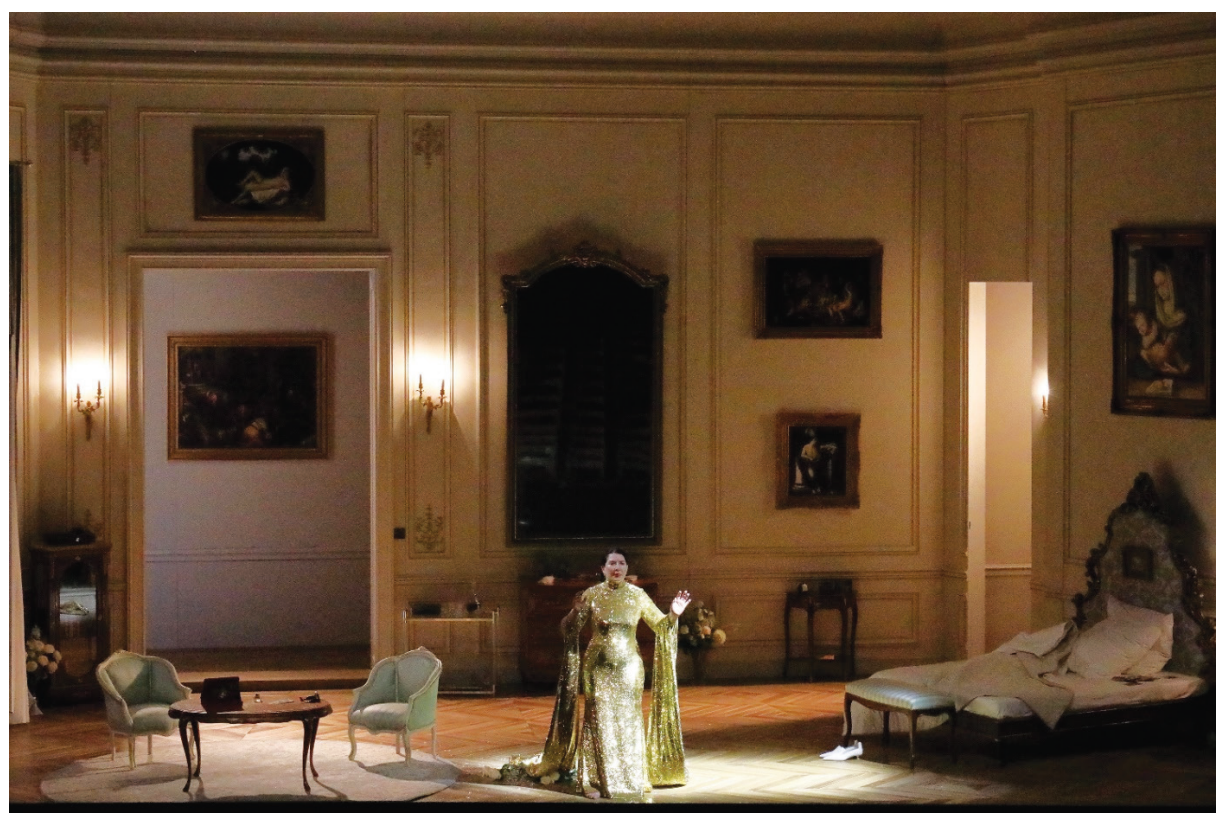

Photo 2. Maria Callas dies of a broken heart from 7 Deaths of Maria Callas. (c) Bayerische Staatsoper, Wilfried Hösl.

\section{Performing death}

How should we interpret Abramović's precence on the stage? We do not know in which role she has been lying there (as Maria Callas, as herself, sleeping, or already dead), nor do we know the meaning of her alleged awakening ("Am I sleeping?"). Whether it is meant to be a dreamlike evocation of Callas' last day, or a representation of the intermediate condition between life and death, in which the dying person sees herself from outside, ${ }^{32}$ we do clearly see elements from two biographies converging. The detailed reconstruction of Callas' apartment and the remembrance of her close acquaintances (her maid Bruna, her ex-husband Meneghini, Bernstein, Zefirelli, Pasolini...) merge with the references to other people relevant for Abramović: the ex-husband, Canevari, through the photograph, but also Willem Dafoe, as artistic partner, as well as fictional symbol for lover, through the

32 For this second possible interpretation see Ein Gespräch mit Marina Abramović, p. 25. 
reuse of the gold sequin dress from the seventh death-scene. This dialectical process culminates in an identification of Marina and Maria in the very last sequence, the pantomime on the aria Casta Diva from Norma, which was Maria Callas' flagship-role. The celebration and process of mythologisation of Maria Callas, of which the entire opera project $>$ Deaths consists, reaches its fulfilment in this final apotheosis, which is reinforced by the mystical imagery of resurrection/eternalisation (Abramović walking into the light) ${ }^{33}$ and of the creative power of the logos (Callas' voice resonating in the end).

Interestingly, we see Callas-Abramović dying on-screen seven times, but the death of Maria Callas in the final scene is not represented, as if it were an irrepresentable and "obscene" event, which has to take place "off-stage" (ob skené), like in the Greek tragedy. ${ }^{34}$ The dramatic destiny of the seven heroines, which Callas interpreted over and over in theatre, is absorbed, as in an oneiric vision, by the body which had been lying in the bed throughout the entire duration of 7 Deaths, but is redeemed in the end and sublimated in a divine picture of the immortal opera "diva", Maria Callas, while we hear from her vocal performance of Casta Diva, the prayer to the Moon: "Chaste goddess... Temper the daring zeal of the burning hearts... Spread on earth the peace that you make reign in heaven."35

Marina Abramović's work has always been a meditation on death. She often uses her performances as a way of exorcising the fear of death: they are concrete signs against the disappearance of her physical presence. ${ }^{36}$ Even though, or raher, precisely because she is terrified by the idea of death, she always tries to overcome her limits and fears. She is "thrilled by the unknown, by the idea of taking risks." 37 As early as the 1970s, she had considered art as "a matter of life and death", as she affirms, quoting Bruce Nauman. ${ }^{38}$ The strength of most of her works is derived, indeed, from her confrontation with those basic human fears of pain, of suffering and of death (which, unlike joy, stimulate creativity) ${ }^{39}$ - all themes that shock, disorient, yet, at the same time attract and "train" the audi-

33 R.J. Brembeck, Die Callas ist tatsächlich auferstanden, "Süddeutsche Zeitung" 2.09.2020, https://www.sueddeutsche.de/kultur/marina-abramovic-maria-callas-nationaltheatermuenchen-1.5018515, sees in 7 Deaths a kind of Dantean itinerary from death to light (leading to ineffable and indescribable just as in the Paradise) and depicts the last scene as a "resurrection" of Callas.

34 For the debate on representation of death in Greek Tragedy, see R.S. Pathmanathan, Death in Greek Tragedy, "Greece \& Rome" 1965, vol. 12, no. 1, pp. 2-14.

35 My translation.

36 See A. Heyward, Die Verletzliche, pp. 26-27.

37 M. Abramović, Walk Through Walls, p. 58.

38 Ibidem, p. 59.

39 See Ein Gespräch mit Marina Abramović, p. 24. 
ence emotionally, in full accordance with the "aesthetics of risk" of which HansThies Lehmann writes. ${ }^{40}$

Of the many episodes in her life, in which Marina Abramović was confronted with death, the funeral of her dear friend, Susan Sontag, in 2004, triggered further reflections: "I've always believed death should be a celebration. Because you're entering a new place, a new state. You're making a major passage. The Sufis say, "Life is a dream and death is waking up ". ${ }^{41}$ That's the moment when Marina Abramović got the idea of planning her funeral as a "going-away party" and a "celebration of all the things I had done, and of my leaving for a new place." 42 Her funeral is supposed to be her last performance, her "final piece."43 The celebration will take place in New York, but there will be three graves, in the three places, in which she lived longest: Belgrade, Amsterdam and New York. Nobody will know in which of these graves her body will actually rest. ${ }^{44}$ But in order to see her own death, at least on a stage, Marina Abramović already acted it under the direction of Robert Wilson in the piece The Life and Death of Marina Abramović. ${ }^{45}$ Again, an exorcism of her fear of death:

I put death in my work very often, and I read a lot about dying. I think it's crucial to include death in your life, to think about death every single day. The idea of being permanent is so wrong. We have to understand that death can appear at any moment, and being ready is essential. ${ }^{46}$

This confrontation with death is, hence, programmatically part of the last two points in Marina Abramović's An Artist's Life Manifesto:

Different death scenarios:

- An artist has to be aware of his own mortality

- For an artist, it is not only important how he lives his life but also how he dies

- An artist should look at the symbols of his work for the signs of different death scenarios

- An artist should die consciously without fear

40 See H.-T. Lehmann, Postdramatic theatre, trans. by K. Jürs-Munby, Routledge, New York 2006, pp. 186-187.

41 M. Abramović, Walk Through Walls, p. 275.

42 Ibidem.

43 Ibidem.

44 Ibidem. For Abramović's will and funeral instructions, see J. Westcott, When Marina Abramović dies, p. xiii.

45 Premiered on July 9, 2011 at the Manchester International Festival, The Lowry, Manchester, United Kingdom.

46 M. Abramović, Walk Through Walls, pp. 334-335. 
Different funeral scenarios:

- An artist should give instructions before his funeral so that everything is done the way he wants it

- The funeral is the artist's last art piece before leaving ${ }^{47}$

\section{Two iconic women}

One of the most powerful description of Maria Callas comes from the pen of the Austrian poet and author Ingeborg Bachmann. Bachmann perfectly depicts Callas' mixture of tragedy and greatness, her fragility, the interdependence of private and artistic life and her intense connection with the public:

She [Maria Callas] is the only creature that ever set foot on an opera stage. [...] All her sentences, breaths, tears, joys, her precision and desire of making art - a tragedy that one doesn't need to know in the usual sense - are evident. [...] She will never make one forget that there are an I and a You, pain and joy; she is great in hate and love, in tenderness and brutality, in each expression [...]. She knows what expressiveness is all about. [...] She never sang roles, but rather lived on the razor's edge [...], she was so present [gegenwärtig]. She is the only person who legitimately went on stage in this century in order to make the listener below freeze, suffer, shiver; she was always the Art [...] and she was always a human being, always the most wretched, the most afflicted, the Traviata. [...] She provided the means for turning listeners on to new worlds: one could suddenly listen through the centuries; she was the last fairy tale. ${ }^{48}$

The idiom "sie hat auf der Rasierklinge gelebt" (she lived on the razor's edge), in particular, catches the essence of Callas' personality and represents, at the same time, a point of intersection with Abramovićs life and work. Both Callas and Abramović devoted themselves - body and soul - to art. Bachmann, and many other witnesses, report that Callas had a liveliness and an authenticity that went far beyond the interpreted roles. She was also ready to sacrifice, as her legendary physical metamorphosis proves: she lost 36 kilos of body weight between 1952 and 1954, in her golden years at Teatro alla Scala, reaching a low of 54 kilos in 1957, in a way that could have irreparably compromised her voice. She went through this in order to reach her artistic ideal to enhance her acting and expressive options on stage.

47 M. Abramović, Writings 1960-2014, Walther König, Köln 2018, pp. 356-357.

48 I. Bachmann, Hommage à Maria Callas, [in:] Werke, ed. C. Koschel, I. von Weidenbaum und

C. Münster, Piper, München 1978, vol. IV (Essays, Reden, Vermischte Schriften, Anhang), pp. 342-343. My translation. 
Her new image contributed, also, to Callas' lifelong goal of modernizing the obsolete standards of the opera genre and opening it up to new audiences and medias. ${ }^{49}$ As far as Abramovićs use of the body and attitude to sacrifice are concerned, these are evident pillars of her entire production, as her statements on pain as "door of secrets" and access to another state of consciousness ("liquid knowledge") show. ${ }^{\mathbf{5 0}}$ To mix discipline and intuition, to enter another dimension, using the body as a medium, is, additionally, something that Callas and Abramović share. The latter often repeats a quote she attributes to Callas, herself: "When I perform, the most important thing is that half of my brain is in complete control and the other part of the brain is totally loose". ${ }^{51}$ This balance between two completely contradictory states - between strength and fragility - is "the magic of a good performance." 52 Abramović seems indeed to paraphrase and gloss Callas' statement, when se attempts to provide a definition of "performance art":

Performance is a mental and physical construction that I step into, in front of an audience, in a specific time and place. [...] You have to do the spinning and you have the possibility of losing control. But at the same time you must have an enormous mental control not to lose it, or you will die. I stage this kind of edgy situation in performance in order to get to the point of elevating the mind. But when you elevate your mind, automatically it is transmitted to the public. That's why it becomes so emotional. ${ }^{53}$

Showing fragility, exposing the body, opening to risk - herein lies the greatest similarity between Maria and Marina, besides the aforementioned biographical

49 G. Guccini, Maria Callas: attrice del Novecento, p. 6.

50 See the interviews Liquid Knowledge, [in:] M. Abramović, Interviews 1976-2018, Abramović LLC, New York 2018, pp. 355-367, in particular pp. 366-367; The Serbian of Pain, ibidem, pp. 383-397, in particular pp. 388-389; Death is Waking Up, ibidem, pp. 251-278, in particular p. 271. For the role of pain in Abramović's performances throughout the decades, see also M. Abramović, Walk Through Walls, pp. 60-61, 74-75, 89, 136-139, 309-310, 314, 319, 339-342. For the centrality of the term "body", in the broadest sense, in Abramović's "body of work", see the trilogy of catalogues edited by Charta: Artist Body. Performances 1969-1998; Public Body. Installations and Objects 1965-2001, Charta, Milano 2001; Student Body. Workshops 1979-2003. Performances 1993-2003, Charta, Milano 2003.

51 See M. Richards, Marina Abramović, New York, Routledge, 2010, p. 133, and among the lectures of the Marina Abramović Institute: https://mai.art/terra-comunal-content/2015/4/9/ fifth-lecture-highlight. See, also, the discussion in M. Abramović et al., Marina Abramović, essays by A. Vettese, G. Di Pietrantonio, A. Daneri, L. Hegyi and Societas Raffaello Sanzio, Milano, Charta, 2002, p. 143.

52 M. Abramović et al., Marina Abramović, p. 143.

53 M. Abramović, The Artist Is Present, Museum of Modern Art, New York 2010, p. 211. 
and physical ones: "The closest link for me - the emotional link - is her mix of extreme strength and extreme fragility at the same time. I see this in me and I see it in Callas." 54 Maria Callas was, to be sure, at her best in those roles that show the most dramatic destinies (agony, suicide, madness...) and that show internal conflicts. ${ }^{55}$ Vulnerability also creates a very powerful connection with the audience. By either showing the drama of the heroines as a mirrored image of her private life (Callas), or by painfully exploring the limits of the human condition (Abramović), both women win empathy and trust from the audience. The spectators are, in both cases, overwhelmed by the aesthetic formalisation of intense emotions, which leads to a process of "transference" 56 - where the artist serves as a "filter" or a "mirror"57 - and pushes the audience, as well, to its emotional and cognitive borders. Or, more precisely, to quote Erika Fisher-Lichte, both artists manage to transform those borders (Grenzen) into thresholds (Schwellen), which is ultimately the goal of the aesthetics of the performative - they realize with their works and with their presence an "art of passage" (Kunst des Übergangs), and invite the audience to take their performances (Aufführungen) "both as life itself and as its model."58

If Abramović programmatically affirms "My work and my life are so connected", Callas, in turn, then, considered her artistic work as being "endless" - in unison with her life. ${ }^{59}$ By virtue of this total dedication to art, to this holistic experi-

54 Ein Gespräch mit Marina Abramović, p. 23, my translation. See also A. Heyward, Die Verletzliche, p. 31. G. Guccini, Maria Callas: attrice del Novecento, p. 10, writes, in this respect, about a "human archetype in which strength and fragility alternate and feed each other, causing continuous oscillations between the extremes" (my translation).

55 E. Rieger, Ecco un artista, p. 55. See also L. Alberti, La scenica scienza, [in:] Mille e una Callas, pp. 53-76 and E. Montale, Prime alla Scala, Arnoldo Mondadori, Milano 1981, pp. 52 and 260.

56 See E. Bronfen, Diven in der Kunstgeschichte, [in:] M. Abramović, 7 Deaths of Maria Callas. Programmbuch, pp. 34-42, especially pp. 39 and 42.

57 For the artist as a "filter", see M. Abramović, The Artist Is Present, p. 211: "the performance [...] is based on energy values. [...] It is crucial that the energy actually comes from the audience and translates through me - I filter it and let it go back to the audience. [...] I really like that moment when the performance becomes life itself". For the artist as "mirror", see Marina Abramović's TED-Talk, An art made of trust, vulnerability and connection, at minute 04:52, https://www.ted. com/talks/marina_abramovic_an_art_made_of_trust_vulnerability_and_connection.

58 E. Fischer-Lichte, The Transformative Power of Performance, p. 205.

59 M. Abramović, Walk Through Walls, p. 118, where Abramović also explains how some of her works have an unconscious meaning that retrospectively illuminates biographical events. For the convergence of private and artistic life in Maria Callas, see E. Rieger, Ecco un artista, p. 58 and E. Bronfen, Diven in der Kunstgeschichte, p. 40. G. Guccini, Maria Callas: attrice del Novecento, p. 43, quotes Callas about this topic: "Our work is timeless. After the rehearsals, back at home, alone in the night, I concentrated and started the real creation [...]. Our destiny is to work endlessly. Art is so huge that the more you know, the more you realise you know nothing" (my translation). 
ence that makes life and art converge, to gradually reducing and eliminating the distinction between private and artistic life, one could venture to include Maria Callas, retrospectively, as well, within the realm of the performance art.

A side effect of this symbiosis between public and private life is, to be sure, the process of mythologising that both Callas and Abramović undergo. A process that transforms the two women into icons - the quintessence, respectively, of opera and performance art. On one hand, it is something controlled by the artists, themselves. One can think of Callas, who the poet Eugenio Montale describes as a "character" deliberately living, also, out of the theatre and who could turn her flaws into virtues (which is the key to becoming a "diva"), 60 or one can think of Abramovićs often repeated anecdotes and memories from her life which she quotes to explain her works, turning her stories into a manner of exegetical parables in this regard. ${ }^{61} \mathrm{On}$ the other hand, however, this mythology around the two women fosters an individual and unpredictable life, as the queer reception of Callas, and the sudden interest for performance - shown by Lady Gaga's young fans - caused by the fascination of the pop star in Abramovićs work, demonstrate, just to name two examples. ${ }^{62}$ Callas and Abramović reach an increasingly large and diverse public. One could say that they talk to masses. Not only were, and are, Callas' operas and recitals, as well as Abramovićs performances and exhibitions, always sold out, attracting people from all over the world, but they also offer a "universal potential" for identification and connection for people. This is, in a way, typical for the divas: "the masses see in them their desires satisfied with a rapid psychological "transfer«. [...] It's clear that the celebrity doesn't belong anymore to art, but to the world of sociological phenomena." ${ }^{33}$ However, behind the sociological aspect, the myths of Callas and Abramović do offer a fertile ground for identification, meditation on pain and life, catharsis and spirituality. ${ }^{64}$ And this awareness for

60 See E. Montale, Dal teatro alla vita, [in:] Prime alla Scala, pp. 49-54 and ibidem, p. 418; E. Montale, Divismo e carità, [in:] Auto da fé. Cronache in due tempi, Arnoldo Mondadori Editore, Milano 1995, p. 295; the entire section II mito, [in:] Mille e una Callas, pp. 405-599.

61 Abramović's biographer, James Westcott, affirms: "I think a lot of her genius it's exactly the mythology she creates for herself and how not only can she do these extreme acts [...], but she knows how to project it, she knows how to communicate it to the world" (Marina: Art vs. Life in the extras of the DVD Marina Abramović. The Arstist is Present, directed by M. Akers, 2011, at minute 00:55).

62 See M. Emanuele, "Every body is a civil war. Callas sang the war": culto della diva e ricezione 'queer', [in:] Mille e una Callas, pp. 77-96 and M. Abramović, Walk Through Walls, pp. 315 and 346-351.

63 E. Montale, Divismo e carità, p. 296.

64 See the sea of people attending Abramović's lectures, or the performance As One (Athens, 2016), where she led 3000 people through 7 minutes of silence (M. Abramović, Walk Through Walls, p. 352; Marina Abramović - The Cleaner, p. 30; M. Abramović, Interviews 1976-2018, 
the deep, meaningful potential on which the myths rely - beyond fame, success, money and the star-status that both Maria and Marina achieved ${ }^{65}$ - is probably the key to not compromising the authenticity and integrity of the artist. Even if the artist has become an icon, "an artist should not make himself into an idol" - writes Abramović in her Manifesto. ${ }^{66}$

On the "lived dichotomy of art and life" that connects Callas and Abramović, Eva Huttenlauch, Curator at the Lenbachhaus in Munich, sheds some light. ${ }^{67}$ According to Huttenlauch, Callas turned her life into a performance and found, for that, a grateful and receptive audience, while Abramović turned performance into her life and approaches the audience with that - challenging the it on a moral, emotional and intellectual level. To go back to Ingeborg Bachmann's quote at the beginning of this section (about Callas living on the razor's edge), it perfectly applies to both women. For the singer, it's about pouring out her emotional life, her inclination to suffering and pain, for the performer it's about giving all of that a precise form - she, literally, grabs the knife and hurts herself. Both attitudes contribute to the myth, and if Callas already is an icon well beyond the opera world, Abramović is not far from becoming one herself:

An icon means, first and foremost, an image, and icons have always been created through reproducible media. [...] Abramović always made sure that her performances were captured in pictures or on video, in order to save her work for a collective memory. That's also what this production [ 7 Deaths] is about - overpowering, by means of these images - at the centre of which she stands. In this respect, she is on the best path for becoming an icon, if she's not one, already. ${ }^{68}$

p. 362). And consider the "long durational performances" and the workshops of the Marina Abramović Institute, where the participants live a process and are the work of art. M. Abramović, Interviews 1976-2018, p. 361: "The public is my work. I am removing myself and the public becomes the work. Everything comes out of each performance experience as a natural flow".

65 For the link between cachet and prestige in Callas, see G. Guccini, Maria Callas: attrice del Novecento, p. 7. For Abramović becoming a "public figure", see M. Abramović, Walk Through Walls, p. 334.

66 M. Abramović, Writings 1960-2014, p. 340. See also the interview in S. Thornton, 33 Artists in 3 Acts, W.W. Norton \& Company, New York 2014, p. 288: "This larger-than-life thing is a dangerous state. Your ego can become an obstacle to your work. If you start believing in your greatness, it is the death of your creativity".

67 Vorbericht mit Interviews by the Munich-based public radio station BR Klassik, presented by Maximilian Maier, 5.09.2020.

68 Ibidem. My translation. 


\section{From performance to opera (and beyond)}

Apart from the implications of the mythologising process, documentation and reproducibility have been, since the 199os, central elements of, not only Abramovićs artistic reflection, but also of performance studies in general. From the first radical performances of the 1970s, where the presence of artist and audience, and the concrete use of the body were a dogma, ${ }^{69}$ up to the opera project 7 Deaths of Maria Callas, the differences are evident, but they mirror a long artistic path, articulated by many intermediate stages. ${ }^{70}$

When asked to list the peculiarities of her first works in comparison to theatre, Abramović answered: "No rehearsals, no repetition, and no predicted end."71 And as far as the documentation is concerned: "The first performances in the early seventies were not even documented because most of us believed that any documentation - by video or photos - could not be a substitute for the real experience: seeing it live."72 But, since the ' 90 s, in order to protect the ephemeral performances from plagiarism and at the same time to "leave some trace of the events for a larger audience," 73 Abramović changed attitude and has started to document her work scrupulously. ${ }^{74}$

69 See the discussion on the "radical concept of presence" and on the "embodied mind" in E. Fischer-Lichte, The Transformative Power of Performance, p. 99. For the centrality of body and presence in the performance art, see ibidem, pp. 67-74 ("Liveness") and pp. 76-107 ("Corporeality").

70 For the gestation of the idea of "reenactment" see T. Gusman, Ciò che resta della presenza: Marina Abramović tra unicità e ripetizione, [in:] R. Carpani, L. Peja, L. Aimo (eds.), Scena madre. Donne personaggi e interpreti della realtà. Studi per Annamaria Cascetta, Vita e Pensiero, Milano 2014, pp. 377-382. On the topic see also A. Jones, "The Artist is Present". Artistic Re-enactments and the Impossibility of Presence, "The Drama Review" 2011, vol. 55, no. 1, pp. 17-45.

71 M. Abramović, Interviews 1976-2018, p. 300. Still in 2015, as far as the performances are concerned, she affirms: "I never rehearsed any of the pieces I performed" (M. Abramović, Walk Through Walls, p. 283).

72 M. Abramović, 7 easy pieces, Charta, Milano 2007, p. 9.

73 Ibidem. For these two arguments in relation to 7 easy pieces, see M. Abramović, Walk Through Walls, p. 279. As examples of plagiarism that caused her "indignation", see the use of her performance with Ulay, Relation in Space, in the photo shoot by Steven Meisel in "Vogue Italia" 1998, no. 579 - also in M. Abramović, 7 easy pieces, p. 8 -, or the use of her performance The House With The Ocean View in the series Sex and the city (M. Abramović, Walk Through Walls, p. 269).

74 Using photography and videos, but also experimenting analogic ways: see the transcription made by James Westcott of every single movement she made in the 12-day-performance The House With The Ocean View (Sean Kelly Gallery in New York, 2002), in M. Abramović, The House With The Ocean View, Charta, Milano 2004, or the fragments of conversations 
Not only was the documentation of a one-time event her goal, but she also sought to maintain the possibility of repeating a performance - the "re-enactment"75 - something that she did regularly with, both, her own performances and those of other well-known colleagues in 7 easy pieces (a re-creation of six famous performances of other artists along with one new performance by her at the Guggenheim Museum in 2005). She also allows other young, trained artists to do the same in the major retrospectives on her work. With 7 easy pieces, Abramović wanted to "open a discussion about whether performance art could be approached in the same way as musical compositions or dance pieces - and also examine how performance can best be preserved."76 But, the idea of a performance as a composition to be interpreted had already emerged, however, in an interview back in 1998:

First I want to go a little bit backward and present a piece about doing performance works as if they are musical scores. I mean, a pianist plays a score by another musician, tells who it is by, yet imprints his own style on it without taking it over. I want to do a series of classic performances by performance artists of the 1970 s but I will be doing all of them myself, like a musician playing Mozart again years later. ${ }^{77}$

It might be ambitious to expect to see a "post-performative turn" in this re-enactment-process that makes a performance reproducible (and hence, no longer unique), as Nikolaus Müller-Schöll does, ${ }^{\mathbf{7 8}}$ because, after all, as Tancredi Gusman, with reference to Erika Fischer-Lichte, noted - the "event" takes place in the realisation of the performance in any case, which is, consequently, not reduced to its planning or its "score". ${ }^{79}$ But, still, it is undeniable that we assist to a process of "dramatization of the performance" (teatralizzazione della performance), as Marco De Marinis defines it. ${ }^{80}$ Whether we agree, or not, with De Marinis' thesis that, even in the purest performance, there is a playful, theatrical, fictional element, and the jeu, as self-representation persists, ${ }^{81}$ we do clearly see how Marina Abramović has, over the decades, been coming closer to the world of the theatre and of "repetition".

captured among the unaware spectators during the performances of 7 easy pieces and printed in M. Abramović, 7 easy pieces.

75 See M. Abramović, 7 easy pieces, pp. 9-11.

76 M. Abramović, Walk Through Walls, p. 278.

77 M. Abramović, Interviews 1976-2018, pp. 203-204.

78 N. Müller-Schöll, Die post-performative Wende, "Theater heute" 2012, no. 12, pp. 42-45.

79 T. Gusman, Ciò che resta della presenza, p. 382.

80 M. De Marinis, Performance e teatro. Dall'attore al performer, e ritorno?, [in:] A. Cascetta (ed.), Il teatro verso la performance, "Comunicazioni sociali" 2014, no. 1, pp. 29-46, in particular pp. 40-42. This phenomenon is complementary to the "performatization of theatre" (performativizzazione del teatro), that can be observed beginning in the 1960 s.

81 Ibidem, p. 42. 
Traces of this can be found in some texts of Abramović, herself. In direct opposition to the manifesto she wrote in 1975 with Ulay for their life on the road, Art Vital, which reads "No repetition" as a commandment, ${ }^{82}$ she writes, in 1991, in her diaries: "The power lies in repetition. [...] Through repetition the ego disappears and one enters into a collective consciousness." ${ }^{83}$ One could also see in these lines - and in the performances of the respective years - a transition from an individualistic conception of art to the collectivism of her more recent presentations. But, besides this, Abramović made very clear statements about how her way of seeing theatre, fiction and reproducibility has changed over the years:

When I was in my 40 , after I ended the walk on the Great Wall of China with Ulay, I was unhappy, depressed and lonely. The only possibility that I saw of freeing myself from the pain of this broken relationship, was to bring my life onto stage as a theatre piece. Through theatre, I wanted to take distance from my life [...]. Until then, I didn't want to do theatre. Theatre and opera were for me enemies of performance art. In theatre, for me, everything was a lie. Someone plays the role of someone else, everything is rehearsed, the audience remains in the dark, nothing is real. In performance art, it's all about the "here and now", every element deals with the truth of the moment. But, at 40 , and as an already established performance artist, I could be much more indulgent with other forms of art - I did not need to fight them anymore. At this point, I wanted to understand them. And theatre was the right medium. ${ }^{84}$

The healing power of theatre was tested by Abramović several times. At first with the piece Biography, in 1992, in which she staged her life and works (with re-performances of old solo works). ${ }^{85}$ It is worth mentioning, here, that in such an autobiographical piece Maria Callas' voice was employed (again her interpretation of Casta Diva) in the so-called "bye-bye scene", her symbolic farewell from the past with Ulay. ${ }^{86}$ In a following version of the biographical piece in 2004, The Biography Remix, Jurriaan, the son of Ulay, played the role of the father in the re-performances showed on stage, and Ulay himself was in the audience to receive Abramovićs farewell: "it was the perfect mixture of life and theatre." ${ }^{37}$ Altogether Abramović

82 M. Abramović, Walk Through Walls, p. 91.

83 M. Abramović, Writings 1960-2014, p. 263.

84 Ein Gespräch mit Marina Abramović, p. 21. My translation.

85 See M. Abramović, Walk Through Walls, pp. 206-210 and M. Abramović, Artist Body. Performances 1969-1998, pp. 385-399.

86 M. Abramović, Walk Through Walls, pp. 207; see ibidem, p. 210, for a memory that combines the listening of Callas with the centrality of the grandmother's kitchen in her young years. See also Ein Gespräch mit Marina Abramović, p. 22.

87 M. Abramović, Walk Through Walls, pp. 273-274. 
had staged her life in five different versions for five different directors, when she decided to make one more version to include her death, as well - the already mentioned Life and Death of Marina Abramović, directed by Robert Wilson in 2011.88 The collaboration with Wilson and co-star, Willem Dafoe, brought Abramović to a further consideration about "truth" on the theatrical stage:

I had always believed performance was real and theatre was fake. In performance art, the knife is real, the blood is real. In theatre, the knife is fake and the blood is ketchup. Despite this illusion, which I had always associated with a lack of discipline, Willem taught me that getting into a role can be every bit as demanding and real as performance art. ${ }^{89}$

From this lesson, Abramović profited in 7 Deaths of Maria Callas, as well: "I learned from Bob Wilson and Willem Dafoe that you can go very deep into it, that you can really become that person. I really felt I became the character. I understood on a deeper level, that I could do that."90 Maybe the compromise that Abramović found between performance art and theatre, with which she goes beyond the polarity Acting/Not-Acting, ${ }^{91}$ lies exactly in this acknowledgment. "In a performance I become, somehow, not like a mortal." 92 What she is not able to show in a performance, the actual death, can only be shown on the theatrical stage - at least until her very last performance, the really unique event of her actual death.

The meditation on death, carried out on stage, is a very personal one, strictly connected with Abramovićs own life: "The only theatre I do is my own. My life is the only life that I can play." 93 This statement reinforces once more the already discussed identification-process with Maria Callas, that allows her to be on stage for 7 Deaths still as "herself". And this is also probably the reason why - together with technical and financial factors - Abramović abandoned the initial idea of How to die, in order not to show another's death on stage (that of the miners but also Callas' death).

Having established Abramović's openness towards theatre - or even her need of it for certain purposes - it remains to be seen how her new opera project will fall within this process of experimentation with new formats. ${ }^{94}$ Opera is, indeed, from

88 Ibidem, pp. 334-338.

89 Ibidem, p. 337. For the differences between theatre and performance, see also Marina Abramović's TED-Talk, An art made of trust, at minute 03:35.

90 A. Heyward, Die Verletzliche, p. 30.

91 M. De Marinis, Performance e teatro, pp. 42-43.

92 A. Heyward, Die Verletzliche, p. 30.

93 S. Thornton, 33 Artists in 3 Acts, p. 292.

94 Two preliminary steps for Abramović on the big opera stage are the production of Maurice Ravel's Boléro in 2013 at the Opéra Garnier in Paris and of Pelléas et Mélisande by the same 
among the stage arts, the most regimented and fixed, and the amount of physical distance experienced between artist and audience (if only because of the architecture of opera houses) is the greatest:

Opera gives a space between audience and the person on stage. So you need much more effort, energy and strength in order to concentrate to actually create an energy-dialogue with the public. So it's a big demand for me. ${ }^{95}$

But, as far as this dialogue is possible, Abramović seems, now, to be open to any kind of medium:

In the beginning of my career, I hated theatre and opera because I had to establish my own rules and position for performance art, in which everything is real and blood is blood. Once I established the rules I could be much more flexible. Media now is not so strict as it was in the early 7os. You can mix things... You must trust the intelligence of the public. ${ }^{96}$

As claimed by Eva Huttenlauch, the fixed dramaturgy (consisting of a script and an orchestral score) and the aesthetic border of the opera stage do not prevent Abramović from approaching Maria Callas extemporaneously, outside of the dynamics of stage direction (which is coherently entrusted to the co-director Lynsey Peisinger), and always anew. ${ }^{97}$ Moreover, the scenic realisation of 7 Deaths works with real, live operating artists. The seven singers do not play as typical a role as in an opera, but sing just a short aria - a short entry in which they have to reach a climax immediately, a couple of minutes of singing - pure voice and presence, the two essential elements to which opera is reduced, here. Finally, even though the course of events is fixed, there is no traditional plot, nor is there a clear directorial line. It is much more about the power and the impact caused by strong images. ${ }^{98}$ And it no longer matters how these images are produced, rather, what effect they have on the audience. That is why Abramović also took part, for the first time

composer in 2018 at the Vlaamse Opera in Antwerpen. For both of them she created the concept and scenography in collaboration with the choreographers Sidi Larbi Cherkaoui and Damien Jalet.

95 See the interview with Abramović in Vorbericht mit Interviews, at minute 01:10.

96 A. Heyward, Die Verletzliche, p. 29.

97 See E. Huttenlauch, Marina Abramović und die Parrhesie, pp. 78-79 and Offen gesprochen. An open conversation, at minute 11:20: "I don't want to act and I'm not an actress. That's why I'm now working with my co-director Lynsey Peisinger, [...] to find my space in this room of Callas. [...] Every emotion has to come out of real emotions".

98 See Vorbericht mit Interviews, where E. Huttenlauch speaks about "Wirkungsmächtigkeit von Bildern". 
in her life, in film shoots in Hollywood, where Nabil Elderkin directed the seven videos - an extremely different filming experience in comparison with the video-performances Abramović has been used to since the 1970s. "E9 "Everything is new for me. [...] It was not easy at all, it was also to learn a very new media for me" - said Abramović about the filming experience. ${ }^{100}$

Abramovićs experimentation with new media and technologies is far from being concluded. Her meditation on how to reach as many people as possible with her art, on the one hand, and her research on the potential of an immaterial art on the other, have already taken her on the path of Mixed Reality (a hybrid of reality and virtual reality) for the "immaterial performance" The Life (London, Serpentine Gallery, 2019). In this performance, audience members were provided with wearable spatial computing devices (similar to Virtual Reality glasses) for seeing and exploring the movements of the artist which were captured in advance through an extensive volumetric process. ${ }^{101}$ The new possibilities of Mixed Reality will probably be further developed and refined in the upcoming, grand retrospective planned at the Royal Academy of Arts in London for autumn 2021, After Life. As the title reveals, after the long gestation of 7 Deaths of Maria Callas, Abramović focuses on life, and on life after death, combining spiritual and technological research:

Spirituality travels so far in front of science, then science finally finds devices to measure its realities. I want to deal with intuitive knowledge. I want to live in synchronicity, where you are so attuned to existence, yourself and your surroundings, that things happen without effort. To have this last period of life, but to see it the way a child sees it. That fresh view: where everything is possible. This is my biggest dream. This is something that is unfinished. ${ }^{102}$

After having used her body as an instrument and object for so many years, ${ }^{103}$ and after having produced so many "transitory objects" for human and non-human use, ${ }^{104}$ Abramović is now completely dedicated to immateriality:

I believe that the twenty-first century will be a world without art in the sense that we have it now. It will be a world without objects, where the human being can be on

99 For the first video see M. Abramović, Walk Through Walls, p. 79. For a backstage documentation of the shooting see M. Abramović, 7 Deaths of Maria Callas, photographs by M. Anelli.

100 Vorbericht mit Interviews, at minute 02:38.

101 See A. Heyward, Die Verletzliche, p. 29, and https://www.serpentinegalleries.org/whats-on/ marina-abramovic-life/

102 M. Abramović, Interviews 1976-2018, p. 359.

103 Ibidem, p. 31.

104 M. Abramović, Public Body. Installations and Objects 1965-2001. 
a high level of consciousness and has such a strong mental state that he or she can transmit thoughts and energy to other people, without needing objects in between. [...] There will just be the artist standing in front of a public, which is developed enough to receive a message or energy. ${ }^{105}$

But in this open research process that she will be carrying on into her final years, she wants to do more than eliminate objects. It seems that she wants to modify, or rather, expand - in space and time, also post mortem - her concept of presence and performance:

At the moment I am transcending my previous understanding of performances by structuring them in such a way that they can also be carried out by others. [...] I am trying to show this is possible through my Abramović Method which is currently being developed at my non-profit organization the Marina Abramović Institute (MAI). Through it, the audience becomes my work. I am still doing performances. However, I would like to reach the point where it is no longer for me to be there physically. Time is necessary to reach this point and I hope I manage to achieve it before I die. ${ }^{106}$

\section{Conclusions}

In the uncertain conditions imposed by the Coronavirus pandemic, Marina Abramovićs opera project 7 Deaths of Maria Callas offers a great opportunity to meditate on performance art and theatre, both on its constituent elements and its relevance to society.

Drawing on her fascination with music, the purest and most intangible form of art, ${ }^{107}$ and, in particular the voice of Maria Callas, Abramović exploits the potential of the genre of opera as a laboratory for cross-mediality. The openness to other media, which has always been one of the salient characteristics of performative theatre, ${ }^{108}$ is taken to its extremes in this project. Moreover, 7 Deaths marks a new stage in Abramović's reflection on the relationship between theatre and performance art, overcoming the polarity representation-presence and finding a new synthesis for it.

105 M. Abramović, Interviews 1976-2018, p. 97. See also V. Spallino, Marina Abramović. Il paradosso dell'assenza. Performance 1967-2017, Villaggio Maori, Catania 2018, pp. 9-33, in particular pp. 31-33.

106 M. Abramović, Interviews 1976-2018, p. 393.

107 M. Abramović, Anders hören. Die Abramović-Methode für Musik, Alte Oper Frankfurt, Frankfurt 2019, p. 16: "For me, music is absolutely the purest form of art [...] because it is intangible. There is no 'object' between it and the recipient: music is always unmediated and direct".

108 A. Cascetta, European Performative Theatre. The Issues, Problems and Techniques of Crucial Masterpieces, Routledge, New York 2020, p. 8. 
The project 7 Deaths revolves around the theme of death, a cornerstone of Abramovićs works. Not only is death the protagonist here in terms of contents, with the aestheticised representation of the deaths of opera heroines and Callas herself, but it also has an impact on the way we perceive both the portrayed and the portraying artists - Callas and Abramović, whose images are fused by virtue of a process of identification that the latter undergoes. Besides the physical resemblance, the two women share a similar attitude towards vulnerability, a comparable relationship with the audience and the same tendency to let artistic and private life coincide - all elements that contribute to making them icons, in a partially controlled and partially autonomous process of mythologisation.

A full and deep reception of the project presupposes that the audience knows, if not the opera plots, at least some aspects of Callas's and Abramović's lives and work. The biographical and autobiographical dimensions play an important part and for this reason the universality of the message is somehow weaker in this than in other works by Abramović. But the visual strength of the videos and of the last scene together with the power of the voice on stage largely compensate for this.

The above-mentioned use of new media and technologies has a significant role in Abramović's current projects and her research into immaterial art - the art of the future according to the Serbian performer, freed from objects and reduced to its essential: the energy-exchange between artist and audience. Immateriality and contemporaneity relate back to the discussion on documentation and re-enactment (a central topic in Abramovićs production), but at the same time open up new prospects for the possibilities of art in the near future. If the performative arts can be considered "a sort of laboratory of live art adapted to the new times,"109 they cannot remain unchanged after such an event as the pandemic we are experiencing, with the constraints and limitations it imposes on culture and the question of how and whether art is relevant to our system. We feel more than ever in these days how necessary and irreplaceable artistic theatre and performance art are, as tools to investigate the phenomenology of existence. ${ }^{110}$ And the new conditions and alternative forms in which we experience art now (for 7 Deaths only 500 spectators could enter the theatre, the others had to view it streamed online) throw up some questions, which, in Abramović's case, contribute to the already operating process of redefining the basics of performance art. The attempt discussed above $\left(\$_{5}\right)$ to expand the concept of presence and performance beyond the physical presence of the artist could be a new path for her art. The conclusion she reached - that the public itself is her work of art ${ }^{111}$ - shifts the focus onto the addressee of the per-

109 Ibidem, p. 6.

110 See C. Bernardi, A. Cascetta, Ci sarà ancora teatro nel mondo che verra?, "Munera" 2020, no. 2 , pp. 111-117, in particular pp. 112-113.

111 See n. 64. 
formance. ${ }^{112}$ Provided that art is not reduced to a superficial experience, to cluster of pixels always accessible on our electronic devices or assimilated to that flow of information that turns us into "emotional invalids", and also provided that we can explore with new tools how to really "be in the moment" with our body and our mind, ${ }^{113}$ art could in future be less bound to a physical place and survive beyond any unpredictable restrictions - such as those imposed by the Coronavirus pandemic. Maybe Abramovićs research is more than a temporary alternative and could be a path for the future, a way to live and perceive art with full awareness, openness and spiritual dedication.

To what extent will she manage to extend the event of her existence, of her "being there" (Dasein)? Will she find a way, as Maria Callas did, with the event of her eternal voice, ${ }^{114}$ to convey to us after her death - the real one, her last performance - her experience, the "full emptiness" and the "positive void"115 that she has found behind the many thresholds that she has crossed, and to preserve her presence for us in the Here and Now?

[...] you have experienced a place I've never explored, A void IN THE COSMOS

It's true that my earth is small

But I've always been happy to spin yarns about unexplored places, as if none of it was real

But you're actually in it, here, in voce P.P. Pasolini, Timor di me? ?16 $^{116}$

112 See T. Girst, Alle Zeit der Welt, Hanser, München 2019, pp. 74-75 for Abramović's idea of rearranging museums worldwide by placing single works of art in little rooms accessible to one single visitor, in order to allow a much more intense and personal encounter with the work.

113 M. Abramović, Anders hören, p. 15.

114 See E. Matassi, La voce come evento, [in:] Mille e una Callas, pp. 21-35.

115 M. Abramović, Interviews 1976-2018, p. 116. The germs of a transcendent concept of presence can be found in the demanding performance Nightsea Crossing with Ulay (performed 90 times between 1981 and 1986), described in M. Abramović, Artist Body. Performances 1969-1998, p. 258 , as a dematerialisation process: "Presence. Being present, over long stretches of time, until presence rises and falls, from material to immaterial, from form to formless, from instrumental to mental, from time to timeless". See also how Abramović broke her silence and announced the conclusion of the last performance (Entering the Other Side) of 7 easy pieces: "Please, just for a moment, all of you, just listen. I am here and now, and you are here and now with me. There is no time" (M. Abramović, Walk Through Walls, p. 283).

116 P.P. Pasolini, The Selected Poetry of Pier Paolo Pasolini, pp. 395-397. 


\section{Bibliography}

Abramović Marina, 7 Deaths of Maria Callas, photographs by Marco Anelli, Damiani, Bologna 2020.

Abramović Marina, 7 Deaths of Maria Callas. Programmbuch zur Uraufführung, mit Beiträgen von Abramović Marina, Bronfen Elisabeth, Bachmann Ingeborg, Rieger Eva und Huttenlauch Eva, Bayerische Staatsoper, München 2020.

Abramović Marina, 7 easy pieces, Charta, Milano 2007.

Abramović Marina, Anders hören. Die Abramović-Methode für Musik, Alte Oper Frankfurt, Frankfurt 2019.

Abramović Marina, Artist Body. Performances 1969-1998, Charta, Milano 1998.

Abramović Marina, Drawings 1963-2017, Henie Onstad, Høvikodden 2018.

Abramović Marina, Interviews 1976-2018, Abramović LLC, New York 2018.

Abramović Marina, Public Body. Installations and Objects 1965-2001, Charta, Milano 2001.

Abramović Marina, Student Body. Workshops 1979-2003. Performances 1993-2003, Charta, Milano 2003.

Abramović Marina, The Artist Is Present, Museum of Modern Art, New York 2010.

Abramović Marina, The House With The Ocean View, Charta, Milano 2004.

Abramović Marina, Writings 1960-2014, Walther König, Köln 2018.

Abramović Marina (with J. Kaplan), Walk Through Walls. A Memoir, Penguin Books, London 2017.

Abramović Marina et al., Marina Abramović, essays by Vettese Angela, Di Pietrantonio Giacinto, Daneri Anna, Hegyi Lóránd and Societas Raffaello Sanzio, Charta, Milano 2002.

Anderson Matthew, The Coronavirus Derails Marina Abramovic's Maria Callas Opera, "New York Times" 9.04.2020, https://www.nytimes.com/2020/04/09/arts/music/ marina-abramovic-maria-callas.html

Aversano Luca, Pellegrini Jacopo (eds.), Mille e una Callas. Voci e studi, Quodlibet, Macerata 2016.

Bachmann Ingeborg, Hommage à Maria Callas, [in:] Christine Koschel, Inge von Weidenbaum und Clemens Münster (eds.), Werke, Piper, München 1978, vol. IV (Essays, Reden, Vermischte Schriften, Anhang), pp. 342-343.

Bernardi Claudio, Cascetta Annamaria, Ci sarà ancora teatro nel mondo che verra?, "Munera" 2020, no. 2, pp. 111-117.

Brembeck Reinhard J., Die Callas ist tatsächlich auferstanden, "Süddeutsche Zeitung" 2.09.2020, https://www.sueddeutsche.de/kultur/marina-abramovic-maria-callasnationaltheater-muenchen-1.5018515

Cascetta Annamaria, European Performative Theatre. The Issues, Problems and Techniques of Crucial Masterpieces, Routledge, New York 2020. 
Cascetta Annamaria (ed.), Il teatro verso la performance, "Comunicazioni sociali" 2014, no. 1.

Essling Lena (ed.), Marina Abramović - The Cleaner, Hantje Cantz, Berlin 2018.

Fischer-Lichte Erika, The Transformative Power of Performance. A new aesthetics, trans. by Saskya Iris Jain, Routledge, New York 2008.

Girst Thomas, Alle Zeit der Welt, Hanser, München 2019.

Guccini Gerardo, Maria Callas: attrice del Novecento, "Acting Archives Review” 2019, vol. 9, no. 17, pp. 1-47.

Gusman Tancredi, Ciò che resta della presenza: Marina Abramović tra unicità e ripetizione, [in:] Roberta Carpani, Laura Peja and Laura Aimo (eds.), Scena madre. Donne personaggi e interpreti della realtà. Studi per Annamaria Cascetta, Vita e Pensiero, Milano 2014.

Heyward Anna, Die Verletzliche, "Max Joseph. Das Magazin der Bayerischen Staatsoper" 2019/20, no. 3 ("Loslassen"), pp. 26-31.

Jones Amelia, "The Artist is Present". Artistic Re-enactments and the Impossibility of Presence, "The Drama Review" 2011, vol. 55, no. 1, pp. 17-45.

Lehmann Hans-Thies, Tragedy and Dramatic Theatre, trans. by Erik Butler, Routledge, New York 2016.

Mann Thomas, Confessions of Felix Krull, confidence man, trans. by Denver Lindley, Vintage International, New York 1992.

Maria Callas alla Scala. Mostra Documentaria a ventanni dalla scomparsa, Teatro alla Scala, Milano 1997.

Montale Eugenio, Auto da fé. Cronache in due tempi, Arnoldo Mondadori Editore, Milano 1995.

Montale Eugenio, Prime alla Scala, Arnoldo Mondadori, Milano 1981.

Müller-Schöll Nikolaus, Die post-performative Wende, "Theater heute" 2012, no. 12, pp. 42-45.

Pasolini Pier Paolo, The Selected Poetry of Pier Paolo Pasolini. A bilingual Edition, ed. and trans. by Stephen Sartarelli with a foreword by James Ivory, University of Chicago Press, Chicago and London 2014.

Pathmanathan R. Sri, Death in Greek Tragedy, "Greece \& Rome" 1965, vol. 12, no. 1, pp. 2-14.

Richards Mary, Marina Abramović, Routledge, New York 2010.

Rossi Francesco, Variazioni poetiche di modelli evolutivi. Thomas Mann e l'Homo aestheticus, "Prospero" 2014, vol. 19, pp. 121-142.

Spallino Valeria, Marina Abramović. Il paradosso dellassenza. Performance 1967-2017, Villaggio Maori, Catania 2018.

Thornton Sarah, 33 Artists in 3 Acts, W.W. Norton \& Company, New York 2014.

Westcott James, When Marina Abramović dies. A Biography, Massachusetts Institute of Technology, Cambridge 2010. 
Francesco Marzano

\title{
Odegrać śmierć: Mariny Abramović 7 śmierci Marii Callas
}

\author{
Streszczenie
}

Esej analizuje projekt operowy Mariny Abramović pt. 7 Deaths of Maria Callas (7 śmierci Marii Callas). Premiera projektu odbyła się w Monachium we wrześniu 2020 roku. W pierwszej część artykułu rekonstruuję rolę, jaką grecki sopran odegrał w życiu serbskiego wykonawcy, wprowadzając go w stopniowe poczucie samoidentyfikacji. Następnie biorę pod uwagę kolejne etapy trzydziestoletniego rozwoju pierwotnej koncepcji utworu wideo How to Die i opisuję szczegółowo etapową realizację dzieła. W trzeciej części koncentruję się na przedstawieniu śmierci w przedstawieniach Mariny Abramović, a w czwartej porównuję dzieła i życie Callas i Abramović oraz ich status jako status kobiet ikonicznych. W ostatniej sekcji przedstawiam artystyczną drogę Abramović, która prowadziła ją od jej ekstremalnych i kluczowych przedstawień $\mathrm{z}$ lat 70 . XX w. do ostatnich eksperymentów z innymi mediami i medytacji nad sztuką niematerialną.

Słowa kluczowe: performance, opera, Abramović, Callas, śmierć, ikony/ikoniczność, obecność

Francesco Marzano - is a graduate student of Modern Philology at the Università Cattolica del Sacro Cuore in Milan (Italy). He has written articles about Giovanni Boccaccio and about European performative theatre. He lives in Cologne (Germany), where he works as flutist and as freelance journalist for the Westdeutscher Rundfunk. 